\title{
Mosquito abundance, bed net coverage and other factors associated with variations in sporozoite infectivity rates in four villages of rural Tanzania
}

\author{
Eliningaya J Kweka*1,2,3, Watoky MM Nkya2,3, Aneth M Mahande 1,2,3, \\ Charles Assenga ${ }^{3}$, Franklin W Mosha ${ }^{2,3}$, Ester E Lyatuu ${ }^{1}$, \\ Charles P Massenga1, Edwin M Nyale ${ }^{3}$, Stephen B Mwakalinga ${ }^{2,3,4}$ and \\ Asanterabi Lowassa ${ }^{5}$
}

\begin{abstract}
Address: ${ }^{1}$ Tropical Pesticides Research Institute, Division of Livestock and Human Disease Vector Control, P.O.Box 3024, Arusha, Tanzania, ${ }^{2} J o i n t$ Malaria programme, P.O.Box 2228, Moshi, Tanzania, ${ }^{3}$ Kilimanjaro Christian Medical Centre, P.O.Box 3010, Moshi, Tanzania, ${ }^{4}$ Centre for Medical Parasitology, Copenhagen University, Denmark and ${ }^{5}$ Tanzania Wildlife Research Institute, P.O.Box 661, Arusha, Tanzania

Email: Eliningaya J Kweka* - pat.kweka@gmail.com; Watoky MM Nkya - mmmnkya@yahoo.co.uk; Aneth M Mahande - Anethf@yahoo.co.uk; Charles Assenga - charlesassenga@hotmail.com; Franklin W Mosha - fwmosha@hotmail.com; Ester E Lyatuu - bingoy2k78@yahoo.com; Charles P Massenga - bingoy2k78@yahoo.com; Edwin M Nyale - bingoy2k78@yahoo.com; Stephen B Mwakalinga - smwakalinga@yahoo.com; Asanterabi Lowassa - alowassa@yahoo.co.uk

* Corresponding author
\end{abstract}

\section{Published: 18 April 2008}

Malaria Journal 2008, 7:59 doi:10.1186/1475-2875-7-59

This article is available from: http://www.malariajournal.com/content/7/I/59

(c) 2008 Kweka et al; licensee BioMed Central Ltd.

This is an Open Access article distributed under the terms of the Creative Commons Attribution License (http://creativecommons.org/licenses/by/2.0), which permits unrestricted use, distribution, and reproduction in any medium, provided the original work is properly cited.
Received: 16 October 2007

Accepted: 18 April 2008

\begin{abstract}
Background: Entomological surveys are of great importance in decision-making processes regarding malaria control strategies because they help to identify associations between vector abundance both species-specific ecology and disease intervention factors associated with malaria transmission. Sporozoite infectivity rates, mosquito host blood meal source, bed net coverage and mosquito abundance were assessed in this study.

Methodology: A longitudinal survey was conducted in four villages in two regions of Tanzania. Malaria vectors were sampled using the CDC light trap and pyrethrum spray catch methods. In each village, ten paired houses were selected for mosquitoes sampling. Sampling was done in fortnight case and study was undertaken for six months in both Kilimanjaro (Northern Tanzania) and Dodoma (Central Tanzania) regions.

Results: A total of 6,883 mosquitoes were collected including: 5,628 (8I.8\%) Anopheles arabiensis, I, I00 (I5.9\%) Culex quinquefasciatus, 89 (I.4\%) Anopheles funestus, and 66 (0.9\%) Anopheles gambiae s.s. Of the total mosquitoes collected 3,86I were captured by CDC light trap and 3,022 by the pyrethrum spray catch method. The overall light trap: spray catch ratio was I.3:I. Mosquito densities per room were 96.5 and 75.5 for light trap and pyrethrum spray catch respectively. Mosquito infectivity rates between villages that have high proportion of bed net owners and those without bed nets was significant $(P<0.00 I)$ and there was a significant difference in sporozoite rates between households with and without bed nets in these four villages $(P<0.00 \mathrm{I})$.

Conclusion: Malaria remains a major problem in the study areas characterized as low transmission sites. Further studies are required to establish the annual entomological inoculation rates and to observe the annual parasitaemia dynamics in these communities. Outdoor mosquitoes collection should also be considered.
\end{abstract}




\section{Background}

Malaria morbidity and mortality in Africa has increased due to an increase of resistance of chloroquine and sulphadoxine-pyrimethamine (SP), insecticidal resistance [1-3] and social economic status [4]. In Tanzania, malaria is the main cause of admission for children (38\%) and adults (32\%) in health facilities [5-7]. Estimates show that 28 million Tanzanians are exposed to the risk of stable malaria, resulting in 16 million clinical episodes per year and 100,000 child deaths over $25 \%$ of total deaths [8].

The levels of transmission of malaria as measured by the entomological inoculation rate are likely to be highly variable among sites in Africa including Tanzania [9]. Awareness of factors contributing to the intensity of malaria transmission over time is extremely important for choosing and targeting malaria control interventions in rural settings. Recent information on malaria transmission intensity in rural Tanzania are inadequate for prevention due to poor recording system within the communities [4].

Therefore, it was the objective of this study to assess the mosquito species composition and host blood meal origin, sporozoite infectivity rates, and bed net coverage within four villages with different ecological characteristics located in two regions of mainland Tanzania.

\section{Materials and methods Study site description}

Four villages, three in the Kilimanjaro region (Rundugai in Hai district, Kisangara in Mwanga district and Ndungu in Same district) and one in the Dodoma region (Chamwino village in Chamwino district) were surveyed. Chamwino, Rundugai and Ndungu are sentinel sites for the monitoring of anti-malarial drug efficacy and were selected by the National Malaria Control Programme in the framework of the East African Network for Monitoring
Anti-malarial Treatment (EANMAT). Such selection, based on past records and the associated ecological diversity, ensured adequate representation of the heterogeneity of malaria endemicity in Tanzania (Table 1). There were no vector control activities in these sites or in the neighbouring areas either before or during the entomological survey, except Ndungu village that in 1958 had performed aerial spray with Dieldrin.

\section{Mosquito sampling and identification}

Mosquitoes were collected inside of selected houses fortnightly using CDC light traps and pyrethrum spray catch methodologies [10]. Morphological classification was used to group and identify adult anophelines mosquitoes [11]. All specimens were stored dry in properly labelled tubes and maintained with silica gel. Species identification of the Anopheles gambiae s.l. was performed using polymerase chain reaction (PCR) [12]. The Anopheles funestus complex was identified to species level using the multiplex PCR technique of Koekemoer et al [13]. The head and thorax of the identified specimens were placed into individual polypropylene microcentrifuge tubes (1.5 $\mathrm{ml}$ ) and dried over silica gel until further processing. Quality control for species identification was ensured by using two separate teams for An. gambiae s.1. and An. funestus morphologic identification as well as PCR processing.

\section{Mosquito sporozoite prevalence}

The involvement of each species in malaria transmission was assessed using an enzyme-linked immunosorbent assay (ELISA) for Plasmodium falciparum sporozoite detection [14]. Monoclonal antibody 2A10, directed against circumsporozoite protein of $P$. falciparum (produced by the New York University), was run on every ELISA test plate. Positive controls consisted of $100 \mathrm{pg}$ and 10pg of a recombinant $P$. falciparum circumsporozoite protein.

Table I: Description of the study villages, their geographical features and meteorological information.

\begin{tabular}{|c|c|c|c|c|}
\hline Study Sites & Rundugai & Kisangara & Ndungu & Chamwino \\
\hline Altitude(M) & 750 & 920 & 1050 & 700 \\
\hline Rainfalls (mm)-2004 & 589 & 290 & 980 & 280 \\
\hline Min.Temp (0C) & 24.7 & 26.7 & 22.1 & 26 \\
\hline Max.Temp (0C) & 29.4 & 31.2 & 29 & 30.3 \\
\hline Landscape & $\begin{array}{l}\text { Rural northern Tanzania; } \\
\text { extensive swamps and } \\
\text { savannah grassland }\end{array}$ & $\begin{array}{l}\text { Peri urban-semi arid, } \\
\text { northern Tanzania }\end{array}$ & $\begin{array}{l}\text { Rural, northern Tanzania, } \\
\text { bare hills, swamps and } \\
\text { grassland. }\end{array}$ & $\begin{array}{l}\text { Rural-central Tanzania, } \\
\text { semi-arid. }\end{array}$ \\
\hline $\begin{array}{l}\text { Ethnic groups and } \\
\text { Economic activities }\end{array}$ & $\begin{array}{l}\text { Masai, Pare and Chagga, } \\
\text { growing maize, vegetable, } \\
\text { rice and keeping large } \\
\text { groups of cattle. }\end{array}$ & $\begin{array}{l}\text { Pare, mainly growing maize } \\
\text { and have cattle heads. }\end{array}$ & $\begin{array}{l}\text { Pare, mainly growing maize, } \\
\text { banana trees, sugarcane, } \\
\text { rice and beans. They have } \\
\text { cattle heads around. }\end{array}$ & $\begin{array}{l}\text { Gogo, Growing maize and } \\
\text { ground nuts, they have large } \\
\text { groups of cattle around } \\
\text { their houses. }\end{array}$ \\
\hline $\begin{array}{l}\text { Any Cattle kept in } \\
\text { compound about } 5 \text { to } 10 \\
\text { meters from sleeping } \\
\text { house. }\end{array}$ & $285(71.4 \%)$ & $605(84.1 \%)$ & $1509(72.5 \%)$ & $702(67.4 \%)$ \\
\hline $\begin{array}{l}\text { Mosquito net in selected } \\
\text { households. }\end{array}$ & $322(81.0 \%)$ & $520(72.3 \%)$ & 1797 (86.0\%) & $512(49.1 \%)$ \\
\hline
\end{tabular}


Mosquitoes from an insectary colony of An. gambiae s.s were used for negative controls. Mosquito samples were tested monthly and each head and thorax was treated singly. Each mosquito head and thorax was placed per well of Elisa plate. Plates were incubated overnight at $4{ }^{\circ} \mathrm{C}$ temperature. In confirmatory tests, samples were considered positive for sporozoite antigens only if the $30 \mathrm{~min}$ absorbance values using 415 nanometres filter in the ELISA plate reader exceeded the mean plus four standard deviation of the eight negative control mosquitoes. All An. gambiae s.l. samples that tested positive by ELISA for $P$. falciparum circumsporozoite protein were identified by PCR for sibling species identification.

\section{Host blood meal identification}

Blood fed mosquitoes collected from the pyrethrum spray catch method were processed for host blood meal identification using the precipitin test [15]. Mosquitoes were smeared onto $9 \mathrm{~cm}$ Whitman filter paper and the blood meal extracted from the filter paper following the precipitin ring test protocol by Bray et al [15] using the human anti-sera at a dilution of 1:10,000.

\section{Meteorological and ecological village data}

Monthly meteorological data were obtained from the Tanzania Meteorological Agency (TMA) located approximately five to six kilometres to each village. Ecological (topographical) data were collected by observation of environmental feature (vegetations) available. Meteorological data analysed included rainfall totals in millimetres and the average minimum and maximum temperatures for the six-month study period

\section{Social economic status}

A detailed questionnaire was used to assess the availability of mosquito nets, numbers and types of animals kept around the house, ethnicity characterization and main economic activities of selected households within each study village. Trained field workers administered questioners in all villages. Head of households were responsible informants in all villages.

\section{Data analysis}

In data analysis, two non-parametric tests were used. In examining the difference among the villages in sporozoite rates, the Kruskal Wallis test was performed. The effect of bed net coverage within villages was evaluated using the nested Mann-Whitney U test. The sporozoite prevalence rate was calculated as the number of positive circumsporozoite protein samples in all anopheline species based on the total number of anopheline species tested in each village.

\section{Ethical consideration}

The ethical clearance was obtained from the Kilimanjaro Christian Medical College of Tumaini university, Institutional Ethics Committee and the National Institute of Medical Research (NIMR) Ethics committee.

\section{Results}

A total of 6,883 anophelines were collected indoors from all selected houses during the six-month study period, An. arabiensis was the predominant vector in each of the four study villages. In Rundugai, An. arabiensis comprised 95\% of the 2,001 total specimens, in Ndungu $69 \%$ of 3,164 , Chamwino $87 \%$ of 1,340 and in Kisangara $100 \%$ of the 378 were An. arabiensis (Figure 1). In Ndungu village $12 \%$, of 3,164 anophelines caught were An. gambiae ss. No An. gambiae ss were found in Kisangara, Rundugai, or Chamwino (Figure 1). An. funestus was found in three of the study sites: Ndungu $(19 \%$ of 3,164$)$, Chamwino $(13 \%$ of 1,340$)$, Rundugai ( $5 \%$ of 2,001 ), however no An. funestus were collected from Kisangara village (Figure 1).

\section{Sporozoite prevalence}

In total, 6,838 Anopheles mosquitoes of which 5,000 were An. gambiae s. 1 and 1,838 An. funestus were tested for $P$. falciparum circumsporozoite protein infection by ELISA (Table 2). Transmission intensity was unstable in Rundugai, Ndungu and Chamwino while in Kisangara it was stable. There was a significant difference in monthly mosquito sporozoite prevalence rates between villages (Kruskal-Wallis $\chi^{2}=13.3, \mathrm{DF}=3, \mathrm{P}=0.004$ ). Chamwino had the highest (5.3\%), with Ndungu (1.3\%) and Rundugai $(1.6 \%)$ showing lowest sporozoite infectivity and no infected mosquito samples were collected from Kisangara during the study period. The monthly infectivity rates are shown in Figure 2.

\section{Host blood meal identification}

In total, 2,465 of the total collected mosquitoes were blood fed. The majority of An. gambiae s.l. 820 (85.7\%) collected had obtained their blood meals from a human host with $135(14.3 \%$ ) having neither bovine nor human bloodmeals (Table 3). Similarly, the majority of Anopheles funestus $720(88.7 \%)$ had taken a blood meal from human source with $92(11.3 \%)$ having an undetectable blood meal host source. On the contrary, 608 (87.1\%) of Anopheles arabiensis had a cattle blood meal, 80 (11.2\%) had a blood meal from humans and 10 (1.4\%) showed a mixed blood meal from both cattle and human (Table 3 ).

\section{Social economic status}

The bed net coverage among surveyed households had a trend as Ndungu, Rundugai, Kisangara, and Chamwino is shown in Table 1, which ranged from $49.1 \%$ to $86.0 \%$. There was significant difference in the groups with and without bed nets $(Z=-3.740, P<0.001)$. The large groups 


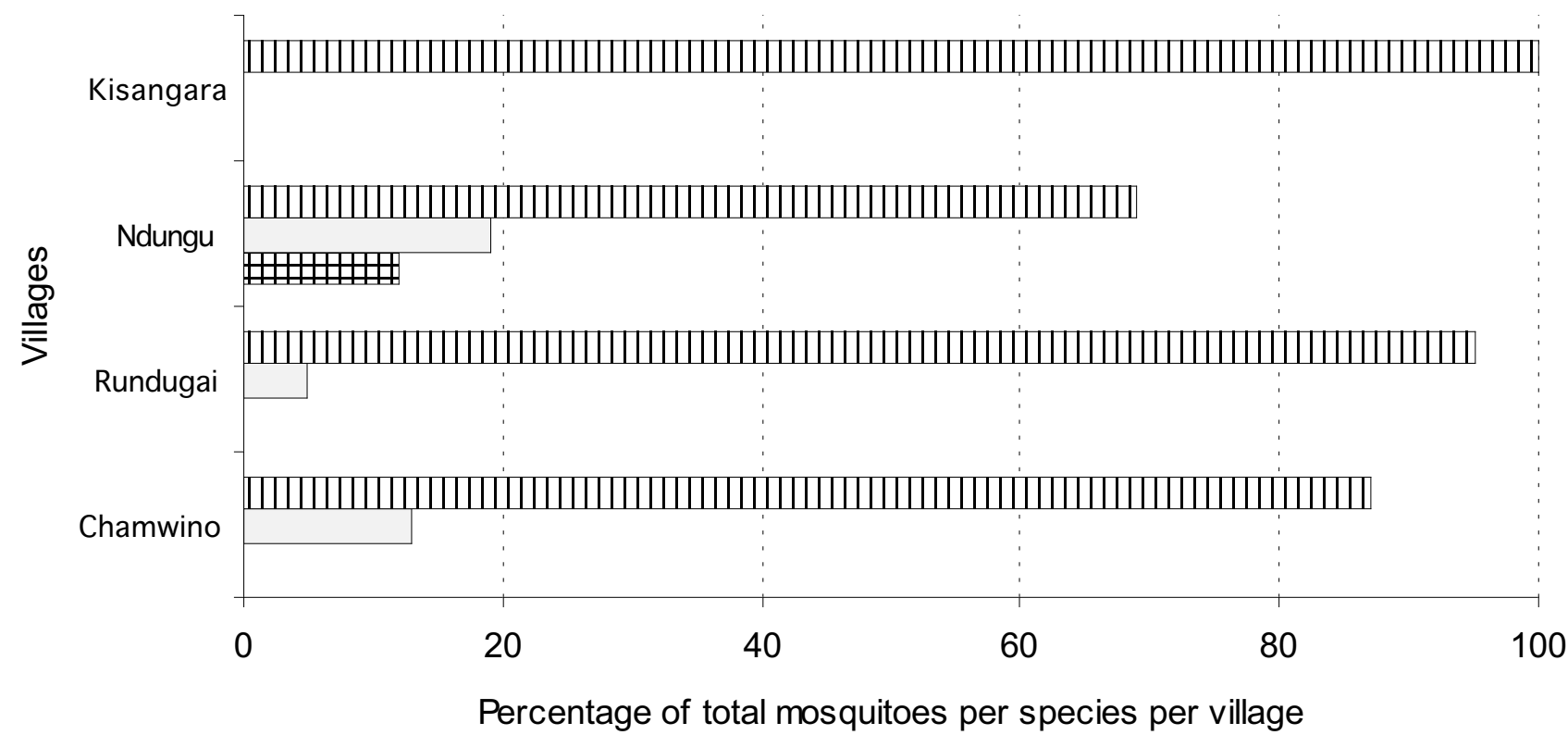

m An.gambiae ss. (\%) घ An.funestus (\%)

n An.arabiensis(\%)

Figure I

Prevalence of Anopheline mosquitoes in four villages, in two regions of mainland Tanzania.

of animals around domiciles for about five to ten metres were observed in all villages (Table 1 ) which ranged between $50.2 \%-84.1 \%$. The groups of cattle around domiciles about five to ten metres have been associated with active malaria reduction [16-18]. Each village had its own agricultural activities that favoured by the weather in the locality (Table 1).

\section{Meteorological data}

Monthly rainfall totals ranged from $280 \mathrm{~mm}$ to $980 \mathrm{~mm}$ during the study period in all villages in which April and May were highest rainfall season and lowest in August and September. Minimum temperature ranged from $22.1^{\circ} \mathrm{C}$ to $26.7^{\circ} \mathrm{C}$ while maximum temperature was between $29^{\circ} \mathrm{C}$ and $33.6^{\circ} \mathrm{C}$. The highest temperatures were experienced in Chamwino village while the lowest was in Ndungu village with mountainous characteristics at an altitude of 1,050 $\mathrm{m}$ above sea level.

\section{Discussion}

Previous studies indicated that An. gambiae s.s, An. funestus and An. arabiensis are major malaria vectors in Tanzania $[19,20]$. The objective of this study was to conduct entomological surveys in four ecological distinct villages to characterize the association of mosquito abundance of these main malaria vectors with sporozoite rates, host

Table 2: Sporozoite prevalence rates for Anopheles mosquitoes testes for circumsporozoite protein in each village monthly.

\begin{tabular}{|c|c|c|c|c|c|c|c|c|c|c|c|c|}
\hline \multirow[b]{2}{*}{ Months } & \multicolumn{3}{|l|}{ Ndungu } & \multicolumn{3}{|c|}{ Kisangara } & \multicolumn{3}{|c|}{ Rundugai } & \multicolumn{3}{|c|}{ Chamwino } \\
\hline & SPR & SPM & $\mathrm{TM}$ & SPR & SPM & TM & SPR & SPM & TM & SPR & SPM & $\mathrm{TM}$ \\
\hline April & 0.3 & I & 310 & 0 & 0 & 210 & 3.8 & 14 & 361 & 10 & 28 & 280 \\
\hline May & 1 & 4 & 410 & 0 & 0 & 206 & 2.7 & 3 & 110 & 0.9 & 1 & 109 \\
\hline June & 0.3 & I & 290 & 0 & 0 & 173 & 0.2 & I & 413 & 8 & 34 & 421 \\
\hline July & 0 & 0 & 150 & 0 & 0 & 359 & 1 & 4 & 390 & 2.9 & II & 370 \\
\hline August & I & 5 & 509 & 0 & 0 & 198 & 0 & 0 & 348 & 0.9 & 3 & 301 \\
\hline September & 5.1 & 10 & 194 & 0 & 0 & 104 & 2 & 5 & 241 & 9 & 34 & 382 \\
\hline Comparison of SPR in villages & & & & & $\chi^{2}=13$ & ; df $=$ & and $P=$ & 0.004 & & & & \\
\hline
\end{tabular}

Key:

SPR = Sporozoite Prevalence rates; SPM = Sporozoite Positive mosquitoes; TM = Total Tested Mosquitoes 


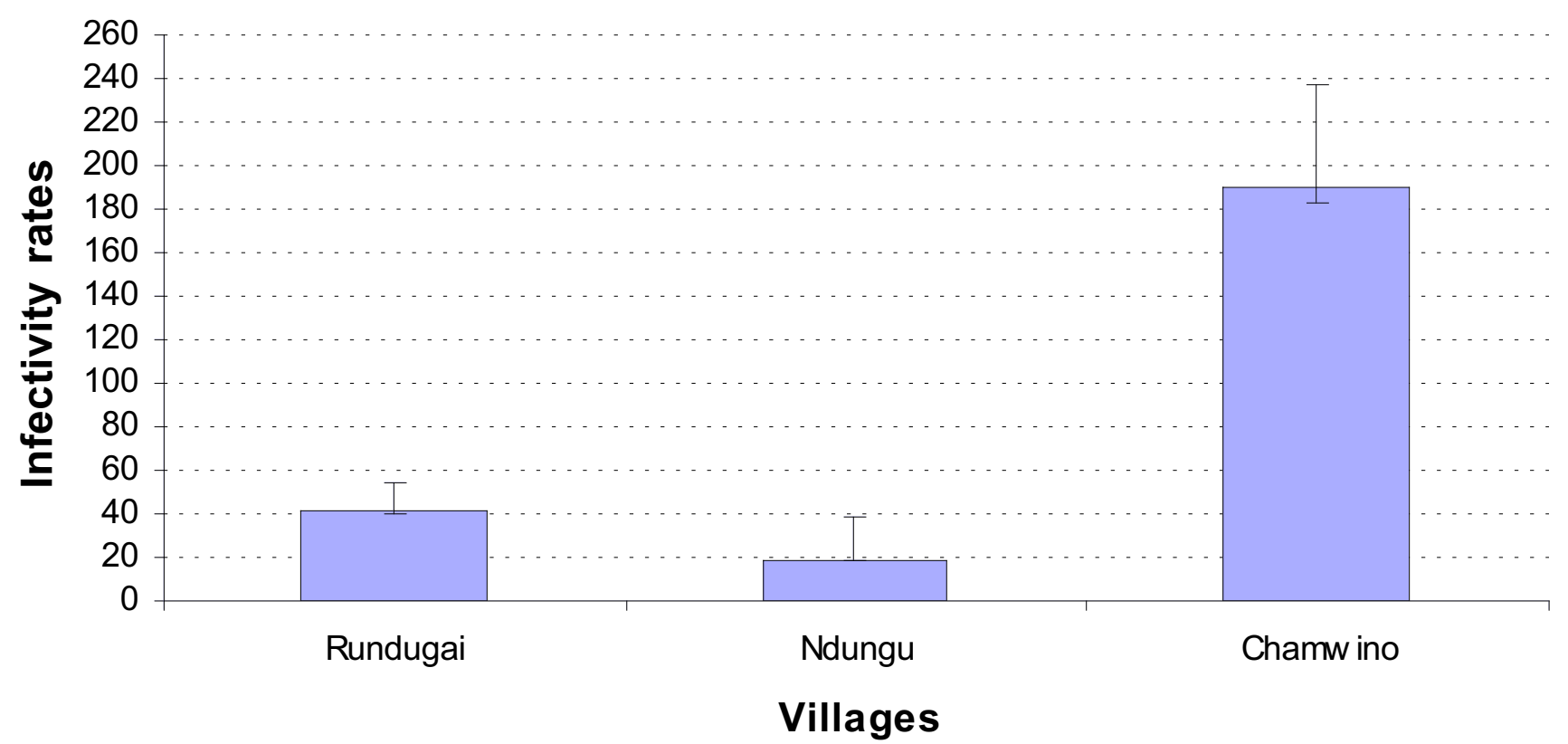

Figure 2

Sporozoite Infectivity rate means among the three study villages that had infected mosquitoes.

blood meal sources and bed net coverage. The sporozoite prevalence rate estimates the level of exposure to the malaria parasite-infected mosquitoes and is a commonly used index for assessing the malaria endemicity and the transmission rate. Weak ELISA reactions were excluded to avoid an over estimation of the sporozoite prevalence rate $[14,21]$. Even distribution of mosquitoes among houses of the same village is rare as adult wild mosquito populations often exist in clusters so that changing the houses sampled could have increased the chances of not capturing the seasonality of the sporozoite prevalence rate [22]. Therefore, in each sentinel site, to estimate the sporozoite prevalence rates and mosquitoes abundance sampling was done in the same twenty houses throughout the surveys, other houses were omitted from the study period due to the absence of house members during trapping days. There was no vector control activities done nearly before or during the study implementation, the estimated sporozoite prevalence rates of malaria vectors could be used as a reference for any vector control program in these villages. Important differences in infectivity rates were observed between the study sites, ranging from $0 \%$ infective rate found in Kisangara to $10 \%$ in Chamwino. In all villages An. arabiensis predominated. These villages had

Table 3: Blood meal origins shown by different mosquito species caught indoors monthly in study villages.

\begin{tabular}{|c|c|c|c|c|c|c|c|c|c|c|}
\hline Host & An. gambiae & & & An. funestus & & & An. Arabiensis & & & \\
\hline & $\begin{array}{l}\text { Sample } \\
\text { Tested }\end{array}$ & Positive (\%) & Negative & $\begin{array}{l}\text { Total } \\
\text { Tested }\end{array}$ & Positive (\%) & Negative & $\begin{array}{l}\text { Total } \\
\text { tested }\end{array}$ & Positive sam & ples (\%) & \\
\hline $\begin{array}{l}\text { Blood } \\
\text { meal } \\
\text { source }\end{array}$ & & Human & & & Human & & & Cattle & Human & $\begin{array}{l}\text { Mixed } \\
\text { (human/ } \\
\text { cattle) }\end{array}$ \\
\hline April & 120 & 104 (86.7\%) & 16 & 125 & $104(83.2 \%)$ & 21 & 117 & $98(83.8 \%)$ & 17 (I4.5\%) & $2(1.7 \%)$ \\
\hline May & 190 & 152 (80\%) & 38 & 109 & 95 (87.1\%) & 14 & 124 & $112(90.3 \%)$ & $12(9.7 \%)$ & $0(0 \%)$ \\
\hline June & 142 & 132 (92.9\%) & 10 & $1 \mid 4$ & 94 (82.4\%) & 20 & 97 & $78(80.4 \%)$ & 16 (I6.5\%) & $3(3.1 \%)$ \\
\hline July & 163 & $126(83.4 \%)$ & 37 & 113 & $109(96.5 \%)$ & 4 & 142 & $130(91.6 \%)$ & $8(5.6 \%)$ & $4(2.8 \%)$ \\
\hline August & 90 & 79 (87.8\%) & II & 140 & II 3 (80.7\%) & 27 & 68 & $51(75 \%)$ & $16(23.5 \%)$ & I (1.5\%) \\
\hline September & 250 & $227(90.8 \%)$ & 23 & 211 & $205(97.2 \%)$ & 6 & 150 & $139(93.7 \%)$ & II (6.3\%) & $0(0 \%)$ \\
\hline
\end{tabular}


average sporozoite prevalence rates $<10 \%$. There was observed monthly variation in infection rates for each village as shown in Table 2 and, therefore, can be classified as unstable malaria areas [23-25]. Anopheles arabiensis played an important role in malaria transmission, but not proportional to its relative abundance. It contributed highest proportion of the overall of the total anophelines collected, but only $18 \%$ of the tested specimens indicated sporozoite infection for Chamwino, Ndungu and Rundugai villages. Drier environments favour An. arabiensis and the adaptation of this species to peri-urban environments has been observed elsewhere in Africa [26]. However, in the rural Ndungu area along the Kalimawe swamp, An. arabiensis is dominant on the valley basin while An. gambiae s.s. is abundant on the down foothills [27]. Similar patterns were observed around the Lake Tanganyika, with predomination of An. arabiensis in the northern valley and An. gambiae s.s. along the southern foothills [28,29]. The observed sporozoites rate values for these four villages are in line with the past findings and recent predictions of malaria endemicity [23]. However, it is important to establish how the observed differences in infectivity rates in Kisangara, Chamwino, Ndungu and Rundugai translate into disease burden and what control effort is needed to decrease transmission in each village.

Results from blood meal identifications indicate that the presence of cattle within the peridomestic environment for about five to ten metres can serve as an alternative blood meal source when the community is well protected by ITNs and the predominate species is An. arabiensis. This data supports previous studies examining anopheline blood meal sources $[16,18,30]$ that describe An. arabiensis to be more attracted to cattle than An. gambiae s.s. It is possible that the proper use of ITNs within a community increases the probability of mosquitoes to exit homes and hence cause animals to be an alternative blood meal source [18,31-33]. Likewise, the proper use of Indoor Residual Spray (IRS) may be better tool in controlling endophagic mosquitoes (An. gambiae s.s.,An. funestus and An. arabiensis) in areas were they are predominant species, such as described by Worrall et al [34] in Zimbabwe.

The insecticide-treated net (ITN) coverage is one of the key interventions for malaria control [6] in rural Tanzania. ITN coverage has a high probability of being effective in controlling malaria because of the endophagic behaviour of the three main vectors (An. gambiae s.s, An. arabiensis and An. funestus) in Tanzania [35]. The lower bed net coverage in Chamwino village $(41 \%)$ has been speculated as the major factor for higher sporozoite prevalence rate due to easier access to a human blood meal. In Ndungu and Rundugai the bed net coverage was above $80 \%$ while in Kisangara the bed net coverage was $72 \%$ which may have provided better community protection [36]. Maxwell et al
$[37,38]$ found that large coverage of ITNs $(75 \%$ and above) provides better protection to the whole community including those without bed nets. Findings from Asembo in Western Kenya indicated that most important reasons for non-adherence to use of ITNs was disruption of sleeping patterns due to visitors, funerals, house constructions and other events [39]. Another study in the same area showed that some people believed that ITNs would only be partly effective due to the perception that malaria has multiple causes [40]. Concerns included fear of the insecticide that is thought by some to be a toxic family planning aid [40]. The poor bed net coverage and malaria transmission in sub-Saharan Africa has been also contributed to poor economic growth rate of these countries $[4,6]$. The effectiveness of ITNs however, is not only measured by the coverage but also includes proper adherence of net use periodic re-treatment of the nets, as well as the vector species involved in the malaria transmission in the region or village [41-43]. In western Kenya, An. funestus was strongly affected by just the presence of at least one treated net within the house, and compliance seems to be less important when An. funestus is the predominant vector such as in Rundugai and Ndungu. Long-lasting insecticidal nets (LLINs) are now available and are the appropriate response for low re-treatment rates of conventional ITNs [44-46]. Educational activities should also play an integral role in malaria control strategies to assure good house design in preventing house entry of vectors and the proper use of ITNs.

\section{Conclusion}

Control measures against infective mosquito bites have a major beneficial impact on malaria morbidity and mortality. Implemented vector control strategies should provide a community-wide health impact that will vary effectively between localities with consideration of high proportions of the disease vector abundance and transmission level. Malaria vector feeding and resting behaviour should be taken into consideration for initiation of malaria control strategies.

\section{Competing interests}

The authors declare that they have no competing interests.

\section{Authors' contributions}

EJK, FWM, SBM and WMMN conceived and designed the study, participated in analysis and interpretation of data and drafted and edited the manuscript. AL did analysis and interpretation of sociological (survey) data. EJK, AMM, CA, EEL, CPM, EMN participated in data collection in the field and laboratory analysis. All authors read and approved the final manuscript.

\section{Acknowledgements}

We would like to thank all the interviewees, field workers in all villages especially, Mr. Manaseh Nkya and Mr. Aza Kimambo for their many hours 
of data collection and entry. Professor Thor G. Theander of Copenhagen University is highly appreciated for obtaining funds from Danish Development Agency required to conduct this study. Mr. Frank Mnango for driving us to and from the study villages. Profs Nicole Achee and John Grieco of Uniformed Service University of the Health Sciences, USA for their constructive comments before submitting this manuscript.

\section{References}

I. Greenwood B, Mutabingwa T: Malaria in 2002. Nature 2002, 4I5:670-672.

2. Mugittu K, Genton B, Mshinda H, Beck HP: Molecular monitoring of Plasmodium falciparum resistance to artemisinin in Tanzania. Malar J 2006, 5: 126.

3. Roper C, Pearce R, Nair S, Sharp B, Nosten F, Anderson T: Intercontinental spread of pyrimethamine-resistant malaria. Lancet 2004, 305: I I23-I I 24.

4. Sachs J, Malaney P: The economic and social burden of malaria. Nature 2002, 41 5:680-685.

5. Gallup J, Sachs J: The economic burden of malaria. Am J Trop Med Hyg 200I, 64:85-96.

6. Magesa SM, Lengeler C, deSavigny D, Miller JE, Njau RAJ, Kramer K, Kitua A, Mwita A: Creating an "enabling environment" for taking insecticide treated nets to national scale: the Tanzanian experience. Malar J 2005, 4:34.

7. Rugemalila J, Wanga C, Kilama W: Sixth Africa malaria day in 2006: how far have we come after the Abuja Declaration? Malar J 2006, 5:102.

8. Ministry of Health: National Malaria Medium-term Strategic Plan, July 2002-June 2006 Dar-es-salaam, Tanzania; 2002.

9. Beier JC, Killeen GF, Githure Jl: Short report: entomologic inoculation rates and Plasmodium falciparum malaria prevalence in Africa. Am J Trop Med Hyg 1999, 61:109.

10. World Health Organization: Manual on practical entomology in malaria. Part II. In Prepared by the WHO division of malaria and other parasitic disease World Health Organ, Geneva; 1975.

11. Gillies TM, de Meillon DB: The Anopheles of Africa South of Sahara (Ethiopian Zoogeographic Region) Volume 54. 2nd edition. Johannesburg, Republic of South Africa. Publication of the South African Institute for Medical Research; 1968.

12. Scott JA, Brogdon WG, Collins FH: Identification of single specimens of the Anopheles gambiae complex by the polymerase chain reaction. Am J Trop Med Hyg 1993, 49:520-529.

13. Koekemoer LL, Kamau L, Hunt RH, Coetzee M: A cocktail polymerase chain reaction assay to identify members of the Anopheles funestus (Diptera: Culicidae) group. Am J Trop Med Hyg 2002, 66:804-8II.

14. Wirtz RA, Burkot TR, Graves PM, Andre RG: Field evaluation of enzyme-linked Immunosorbent assays for Plasmodium falciparum and Plasmodium vivax sporozoites in mosquitoes (Diptera: Culicidae) from Papua New Guinea. J Med Entomol 1987, 24:433-437.

15. Bray RS, Gill GS, Killick-Kendrick R: Current and possible future technique for the identification of bloodmeals of vector haematophagous arthropods. World Health Organ WHO/VBC/84.905 1984.

16. Duchemin JB, Tsy JM, Rabarison P, Roux J, Coluzzi M, Costantini C: Zoophily of Anopheles arabiensis and An. gambiae in Madagascar demonstrated by odour-baited entry traps. Med Vet Ento$\mathrm{mol}$ 200I, I 5:50-57.

17. Mahande A, Mosha FW, Mahande JM, Kweka EJ: Role of cattle treated with deltamethrine in areas with a high population of Anopheles arabiensis in Moshi, Northern Tanzania. Malar J 2007, 6:109.

18. Mahande AM, Mosha FW, Mahande JM, Kweka EJ: Feeding and resting behaviour of malaria vector, Anopheles arabiensis with reference to zooprophylaxis. Malar J 2007, 6:100.

19. Temu EA, Minjas JN, Coetzee M, Hunt RH, Shift CJ: The role of four anopheline species (Diptera: Culicidae) in malaria transmission in coastal Tanzania. Trans R Soc Trop Med Hyg 1998, 92:152-158.

20. Mnzava A, Kilama W: Observations on the distribution of the Anopheles gambiae complex in Tanzania. Acta Trop 1986, 43:277-283.
21. Fontenille D, Meunier JY, Nkondjio CA, Tchuinkam T: Use of circumsporozoite protein enzyme-linked immunosorbent assay compared with microscopic examination of salivary glands for calculation of malaria infectivity rates in mosquitoes (Diptera: Culicidae) from Cameroon. J Med Entomol 200 I, 38:45।-454.

22. Ndyomugyenyi $\mathrm{R}$, Magnussen $\mathrm{P}$ : Trends in malaria attributable morbidity and mortality among young children admitted in Ahandan hospitals for the period 1999-200 I. Ann Trop Med Parasitol 2004, 98:3।5-327.

23. Hay SI, Rogers DJ, Toomer JF, Snow RW: Annual Plasmodium falciparum entomological inoculation rates (EIR) across Africa: literature survey, internet access and review. Trans $R$ Soc Trop Med Hyg 2000, 94: I I3-I 27.

24. Beier JC, Killeen GF, Githure J: Entomological inoculation rates and Plasmodium falciparum malaria prevalence in Africa. Am J Trop Med Hyg 1999:109-II 3.

25. Takken W, Lindsay SW: Factors affecting the vectorial competence of Anopheles gambiae : a question of scale. In Ecological aspects for application of Genetically modified mosquitoes Edited by: Scott WT. TW. Dordretch: Kluwer Academic publishers; 2003:75-90.

26. Charlwood JD, Smith T, Lyimo E, Kitua AY, Masanja H, Booth M, Alonso PL, Tanner M: Incidence of Plasmodium falciparum infection in infants in relation to exposure to sporozoite-infected anophelines. Am J Trop Med Hyg 1998, 59:243-25I.

27. Coluzzi M, Sabatini A, Petrarca V, Di Deco MA: Chromosomal differentiation and adaptation to human environments in the Anopheles gambiae complex. Trans R Soc Trop Med Hyg 1979 , 73:483-497.

28. Coosemans M, Petrarca V, Barutwanayo M, Coluzzi M: Species of the Anopheles gambiae complex and chromosomal polymorphism in a rice-growing area of the Rusizi Valley (Republic of Burundi). Parassitologia 1989, 3 I(1): I I3-122.

29. Smits A, Roelants P, Van Bortel W, Coosemans M: Enzyme polymorphisms in the Anopheles gambiae (Diptera:Culicidae) complex related to feeding and resting behavior in the Imbo Valley, Burundi. J Med Entomol 1996, 33:545-553.

30. Mutero CM, Kabutha C, Kimani V, Kabuage L, Gitau G, Ssennyonga J, Githure J, Muthami L, Kaida A, Musyoka L, Kiarie E, Oganda M: A transdisciplinary perspective on the links between malaria and agroecosystems in Kenya. Acta Trop 2004, 89: I7I-186.

31. Lines JD, Myamba J, Curtis CF: Experimental hut trials of permethrin-impregnated mosquito nets and eave curtains against malaria vectors in Tanzania. Med Vet Entomol 1987, I:37-51.

32. Snow RW, Rowan KM, Greenwood BM: A trial of permethrintreated bed nets in the prevention of malaria in Gambian children. Trans R Soc Trop Med Hyg 1987, 8 I:563-567.

33. Killeen GF, Smith TA: Exploring the contributions of bed nets, cattle, insecticides and excitorepellency to malaria control: a deterministic model of mosquito host-seeking behaviour and mortality. Trans R Soc Trop Med Hyg 2007, 101:867-880.

34. Worrall E, Connor S, Thomson M: A model to simulate the impact of timing, coverage and transmission intensity on the effectiveness of indoor residual spraying (IRS) for malaria control. Trop Med Int Health 2007, 12:75-88.

35. Msuya FH, Curtis CF: Trial of pyrethroid impregnated bednets in an area of Tanzania holoendemic for malaria. Part 4. Effects on incidence of malaria infection. Acta Trop 1991, 49:165-17|.

36. Maxwell CA, Msuya E, Sudi M, Njunwa KJ, Carneiro IA, Curtis CF: Effect of community-wide use of insecticide-treated nets for 3-4 years on malarial morbidity in Tanzania. Trop Med Int Health 2002, 7:1003-1008.

37. Maxwell CA, Wakibara J, Tho S, Curtis CF: Malaria-infective biting at different hours of the night. Med Vet Entomol 1998, I 2:325-327.

38. Maxwell CA, Chambo W, Mwaimu M, Magogo F, Carneiro IA, Curtis CF: Variation of malaria transmission and morbidity with altitude in Tanzania and with introduction of alphacypermethrin treated nets. Malar J 2003, 2:28.

39. Alaii JA, Hawley WA, Kolczak MS, ter Kuile FO, Gimnig JE, Vulule JM, Odhacha A, Oloo AJ, Nahlen BL, Phillips-Howard PA: Factors affecting use of permethrin-treated bed nets during a randomized controlled trial in western Kenya. Am J Trop Med Hyg 2003, 68:|37-|4|. 
40. Alaii JA, van den Borne HW, SP K, Mwenesi H, Vulule JM, Hawley WA, Meltzer ML, Nahlen BL, Phillips-Howard PA: Perceptions of bed nets and malaria prevention before and after a randomized controlled trial of permethrin-treated bed nets in western Kenya. Am J Trop Med Hyg 2003, 68: I42-I 48.

4I. Aikins MK, Pickering H, Greenwood BM: Attitudes to malaria, traditional practices and bednets (mosquito nets) as vector control measures: a comparative study in five West African countries. J Trop Med Hyg 1994, 97:8I-6.

42. Aikins MK, Pickering $H$, Alonso PL, D'Alessandro U, Lindsay SW, Todd J, Greenwood BM: A malaria control trial using insecticide-treated bed nets and targeted chemoprophylaxis in a rural area of The Gambia, West Africa. 4. Perceptions of the causes of malaria and of its treatment and prevention in the study area. Trans R Soc Trop Med Hyg 1993, 87:25-30.

43. Barat L: Four malaria success stories: how malaria burden was successfully reduced in Brazil, Eritrea, India and Vietnam. Am J Trop Med Hyg 2006, 74: I2-16.

44. Hodjati MH, Mousavi N, Curtis CF: Irritant effect, prevention of blood feeding and toxicity of nets impregnated with different pyrethroids on An. stephensi. J Vect Borne Dis 2003, 40(1-2):54-59.

45. Lengeler C: Insecticide-treated bednets and curtains for preventing malaria. Cochrane Database Syst Rev 2004:CD000363.

46. Tami A, Mubyazi G, Talbert A, Mshinda H, Duchon S, Lengeler C: Evaluation of Olyset insecticide-treated nets distributed seven years previously in Tanzania. Malar J 2004, 3:19.

Publish with Biomed Central and every scientist can read your work free of charge

"BioMed Central will be the most significant development for disseminating the results of biomedical research in our lifetime. "

Sir Paul Nurse, Cancer Research UK

Your research papers will be:

- available free of charge to the entire biomedical community

- peer reviewed and published immediately upon acceptance

- cited in PubMed and archived on PubMed Central

- yours - you keep the copyright

Submit your manuscript here:

http://www.biomedcentral.com/info/publishing_adv.asp
BiolMedcentral 